\title{
Heavy Metal Contaminants Removal from Wastewater Using the Potential Filamentous Fungi Biomass: A Review
}

\author{
Shafiquzzaman Siddiquee ${ }^{1 *}$, Kobun Rovina ${ }^{1}$, Sujjat Al Azad ${ }^{2}$, Laila Naher ${ }^{3}$, Saallah Suryani ${ }^{1}$ and Pasicha Chaikaew ${ }^{4}$ \\ ${ }^{1}$ Biotechnology Research Institute, Universiti Malaysia Sabah, JIn UMS, Sabah, Malaysia \\ ${ }^{2}$ Borneo Marine Research Institute, Universiti Malaysia Sabah, JIn UMS, Sabah, Malaysia \\ ${ }^{3}$ Faculty of Agro Based Industry, Universiti Kelantan Malaysia, Kelantan \\ ${ }^{4}$ Department of Environmental Science, Faculty of Science, Chulalongkorn University, Bangkok, Thailand
}

\begin{abstract}
Heavy metal pollution of wastewater currently becomes a key environmental problem throughout the whole world. Conventional methods for the removal of heavy metals from aqueous solutions are not economically and environmental friendly because it has produced massive quantity of toxic chemical compounds. Recently, the removal of heavy metals from wastewater are extensively used various conventional methods such as chemical precipitation, coagulation-flocculation, flotation, ion exchange and membrane filtration. Biological treatments, especially filamentous fungi have gained an increasing attention for heavy metal removal and recovery due to their upright performances, low cost and huge quantities. The filamentous fungi have a great potential to produce large amount of biomasses which are widely used for metal adsorption capacities of $\mathrm{Pb}, \mathrm{Zn}, \mathrm{Cd}, \mathrm{Cu}, \mathrm{Cr}, \mathrm{As}$ and $\mathrm{Ni}$. Production of biomass has offered great potential for adopting metal-recovery system. The main aim of this review paper is to discuss the available information of heavy metals removal for the utilization of filamentous fungi biomass and scrutinize the practical of exploiting them for heavy metal remediation.
\end{abstract}

Keywords: Heavy metals; Filamentous fungi; Wastewater; Bio sorption; Biomass

\section{Introduction}

The soil and water contaminations are frequently occurred by toxic heavy metals and organic pollutants as a consequence of human activities become a key concern in environmental and health problem. Several toxic metals ( $\mathrm{Cd}, \mathrm{Cu}, \mathrm{Hg}, \mathrm{Pb}, \mathrm{Mn}, \mathrm{As}, \mathrm{Ni}, \mathrm{Zn}$, etc.) from industrial wastewater and other human activities are directly or indirectly released into the environment. Unlike organic contaminants, these pollutants from heavy metals are not biodegradable and able to travel up the food chain via bioaccumulation. According to Lopez and Vazquez [1], some metals including $\mathrm{Cu}, \mathrm{Fe}, \mathrm{Mn}$ and $\mathrm{Zn}$ are micronutrients for most of the organisms; however, not all living organism. It can play a vital role in metalloenzymes. Cations usually increase membrane stability and play specific roles in nucleic acid structures, functions and metabolisms [2]. When the concentrations of beneficial metals (mercury, lead, cadmium) in the environment are very high, they become more toxic $[2,3]$.

Volesky [4] and Domenech [5] shortlisted some available conventional methods for removing the dissolved heavy metals including chemical precipitation and sludge separation, chemical oxidation or reduction, ion exchange, reverse osmosis, filtration, adsorption using activated charcoal, electrochemical treatment and evaporative recovery. These physio-chemical techniques are costly and may not always be practicable, and also their metal-binding properties are non-specific [6]. The removal of heavy metals is more taken into consideration when using microbial biomass [4].

Naturally fungi have a large variety of extracellular proteins, organic acids and other metabolites. Fungi can adapt in any ecosystems and any environmental conditions [7]. Most of the soil fungi, especially, the filamentous fungi of Trichoderma are a great interest in agriculture. Trichoderma species is commonly found in root, soil, foliar environments and all environmental conditions. It can grow faster, high strong spore producers, cell wall degrading enzymes, biocontrol agent and eco-friendly in natures [8]. It has high resistant towards various toxins and xenobiotic compounds, including antibiotics, fungicides and heavy metals [9]. Benítez et al. [10] have reported that some potential Trichoderma strains are possessed good antagonistic abilities against some plant pathogenic fungi. Kredics et al. $[11,12]$ have suggested that only mercury $(\mathrm{Hg})$ do not cause any inhibition of extracellular enzyme production in the mycoparasite. For that reason, T. harzianum is more effective under heavy metal stress condition towards mycoparasitisms.

\section{Heavy Metals}

Heavy metals are defined on the basis of three different criteria which including density, atomic number or their chemical properties. Radojevic et al. [13] have mentioned that heavy metals can be defined by density of such metals $\left(5 \mathrm{~g} / \mathrm{cm}^{3}\right)$ which is denser than water by five times. $\mathrm{Yu}$ [14] categorized metals as any elements with an atomic number of higher than 20 excluding alkaline metals, alkaline earth, lanthanides and actinides. In sewage water, concentration of $\mathrm{Zn}$ is found highest value compared to other heavy metals as shown in Table $1[15]$.

\section{Pollution and diseased caused by heavy metals}

The existing heavy metals in the environment and industrial

*Corresponding authors: Biotechnology Research Institute, Universiti Malaysia Sabah, Jln UMS, Sabah, Malaysia, Tel: 60 88-320 000; E-mail: shafiqpab@ums.edu.my

Received October 05, 2015; Accepted October 30, 2015; Published November 06, 2015

Citation: Siddiquee S, Rovina K, Azad SA, Naher L, Suryani S, et al. (2015) Heavy Metal Contaminants Removal from Wastewater Using the Potentia Filamentous Fungi Biomass: A Review. J Microb Biochem Technol 7: 384-393. doi:10.4172/1948-5948.1000243

Copyright: (c) 2015 Siddiquee S, et al. This is an open-access article distributed under the terms of the Creative Commons Attribution License, which permits unrestricted use, distribution, and reproduction in any medium, provided the original author and source are credited. 


\begin{tabular}{|c|c|}
\hline Type of metals & Concentration $\left(\mathrm{mgL}^{-1}\right)$ \\
\hline $\mathrm{Cd}$ & 10 \\
\hline $\mathrm{Ni}$ & 60 \\
\hline $\mathrm{Cr}$ & 240 \\
\hline $\mathrm{Pb}$ & 450 \\
\hline $\mathrm{Cu}$ & 700 \\
\hline $\mathrm{Zn}$ & 2600 \\
\hline
\end{tabular}

Table 1: Metals concentration $\left(\mathrm{mgL}^{-1}\right)$ in sewage [15]

wastewater increasingly pollute ecosystems and threaten human health in-the developing countries. Different concentrations of heavy metal elements commonly occur in all ecosystems. Several compounds have diverse properties such as $\mathrm{Zn}, \mathrm{Cu}, \mathrm{Ni}, \mathrm{Fe}$ and $\mathrm{Mn}$ are essential trace elements for living organisms [16]. The high level accumulation of these metals or ingested in greater amounts than the required concentration can produce serious problem towards living things including human being. Alleviating of heavy metal concentration in water is crucial to the quality of aquatic living organisms. In addition, heavy metals can cause severe toxic effects to expose plants, animals and human when presence in the excessive concentrations [16]. The wastes containing metals are directly or indirectly being discharged into the environment producing serious environmental pollution and possess a major threat toward human, soil and sediments health $[17,18]$.

Arora et al. [19] have reported that heavy metals have the ability to accumulate in different parts of human body. Heavy metal concentrations have the characteristic of having long biological half-lives as well as resistant to degradable process and exhibit their chemical toxicity in soluble water. For this reason, the heavy metals are considered as a threat to human and other organisms even though when present in low concentration. When the concentration of heavy metals is entered the human body through absorption, these metals ion can bind various biomolecules such as proteins, nucleic acid and interfere with their functions [14].

\section{Contaminations of heavy metals in environments}

Rapid developments of industrializations and urbanizations have led to the direct impact of the environment. The resultant degradation and contamination of ecosystem become a major threat toward all living organisms worldwide, in particular, human beings. Globally, open water and aquatic ecosystems are contaminated with several heavy metals through various human activities that indirectly or directly lead to these pollutions [20]. The most serious water pollutions have occurred with some water bodies such as rivers, lakes, oceans and groundwater. In additions, high amount of materials can change the water properties and polluted the water, thus resulting in unfit for intended uses. The water pollution can be classified into two distinct types that are point sources and nonpoint sources [20].

The point sources of pollutions are single identifiable localized sources of water pollution. It can occur when harmful substances are emitted directly into the water bodies. Examples of water pollution are the Exxon Valdez oil spills in 1989 that ran aground in the Price William Sound causing expelling of 11 million gallons of crude oil into the Alaska environment [20]. The nonpoint source pollution is affecting the water body from the diffusion sources such as polluted runoff from agricultural areas draining into the river and oceans waters. Besides, the nonpoint sources pollutions are derived and come from many different sources which made it difficult to find the specific solution to stop the pollution.

\section{Types and toxicity effects of heavy metals}

Zinc: Zinc $(\mathrm{Zn})$ covers about $0.004 \%$ of the earth crust with atomic number of 30 and atomic relative number of 65.39 . $\mathrm{Zn}$ has the average content approximately $80 \mathrm{ppm}$ in lithosphere and between 10-300 ppm in soil [21]. Zinc is a one of major metal that can be found in effluents discharged from industries [22,23]. Most of the industries are released zinc as their waste material which includes electroplating, manufacture of batteries, galvanization and metallurgical industries [23]. Zn can play an important role on plant growth. The growth slows down when $\mathrm{Zn}$ is deficient in the environment. Functional group of $\mathrm{Zn}$ can increase the stabilization of plant by altering its structure molecule and its membrane as well as act as the defensive mechanism against disease for the plant. Basically, zinc in metallic form does not cause any harm towards the environments and it has limited bioavailability. However, the presence of other chemicals such as acids and oxygen can react with zinc to form a potentially toxic compound which can cause severe damage to biological systems [24].

Copper: Copper is recognized another metal and contributed the heavy metals pollution or contamination. Copper $(\mathrm{Cu})$ mostly found deep inside the earth. It is rare element which is found in nature in the un-combined state as well as in ores such as chalcopyrite [25]. According to Davies and Bennett [26], copper is classed as the transition element in periodic table and included among 25 elements that are found inside earth crusts that have the atomic number of 29 and atomic weight of 63.55. The pollution of $\mathrm{Cu}$ in environment may have caused by animal manure. After that, $\mathrm{Cu}$ is used as supplement for inhibition of parasites as well as the industrial factory such as paint factory and the disposed by electronic and electrical factory [27]. The anthropogenic sources of copper element is mostly found in pollution sites from landfills, mine sites, combustion of fossil fuels and domestic waste waters. It can be released by particles from volcanoes, dust and forest fire into atmosphere or dissolved compound in water.

The contamination of copper metals can be hazardous to human health. Its can affect human either by its toxicity or by chronic diseases. The contamination of copper can cause severe damage of kidney and liver and even death when consume in high concentrations. The accumulation of $\mathrm{Cu}$ in the organs and the toxicity inside human bodies are increased with the decreasing of zinc element and sulphate ion [28] and also threaten the fish population. When the presence of heavy metal is highly found in fish's body, it can adversely alter the functional organ system. [29]. Even though copper play important activities in several enzymes for production of haemoglobin, it has detrimental effects towards some facts of the organisms. In living things, $\mathrm{Cu}$ is essential for living organisms as it acts as an antioxidant, participating in the electron transport chain as well as in collagen and elastin. This micronutrient is only required in certain amount which mostly accumulated inside human's tissues [30].

Nickel: Apart from Copper, nickel is known as major environment pollutant. It has possessed the potential of clastogenic, toxic and carcinogenic effect. The different solubility of nickel compound has different carcinogenic potentials. Dunnick et al. [31] have stated that insoluble $\mathrm{Ni}_{3} \mathrm{~S}_{2}$ or $\mathrm{NiO}$ is strong carcinogens while the soluble nickel salts are presented as weak carcinogens. Nickel is commonly an airborne contaminant in the form of nickel carbonyl $\mathrm{Ni}(\mathrm{CO})_{4}$, an intermediate product of refining nickel activity which enter the body through respiratory system. It has a high toxic volatile liquid that can cause death when inhaled and lead to several health problems such as pulmonary edema, pneumonia and respiratory failure [14]. Crosby [32] reported that some individuals have higher sensitivity towards nickel 
compounds even having minimal contact with nickel plate or coins could result in irritation on their exposed part of body. The sources and the effects of heavy metals concentrations towards the environment are shown in Table 2 [22].

Heavy metals pollution cases: Accumulation of different types of heavy metals (e.g., $\mathrm{Pb}, \mathrm{Cd}, \mathrm{Cu}, \mathrm{Ni}, \mathrm{Zn}$, and $\mathrm{Mn}$ ) in the sea water not only contaminated the water but also occurred in soil. It is affecting the sources of drinking and building up the dangerous concentration of heavy metals in grains and vegetables. There are several cases involved with the heavy metals contaminations which occurred in 1963 in Minamata Bay, Japan. Its tragedy has related with local people who consumed shellfish that contained high amount of mercury concentration near the Minamata Bay. The exposure of these diseases occurred due to the chemical substances that released and discharged without controller by the chemical factory which operate near to the bay [33]. High amount of mercury concentration is discharged into the sea as wastewater and affect the marine foods chains such as shellfish and other seafood which can build high concentration of mercury than become poisonous to the locals who are consumed them [33].

Concentrations of heavy metals in environments are increased continuously which can cause toward food chain in the environment and become a major human health hazard. Heavy metals are one of the most serious environment pollutants so that it can be derived from both direct sources such as industrial effluents, sludge dumping and indirectly through highway runoffs. As results of these problems, the great interest in metal-microbe interactions have arisen by the researcher and also industrialists to find the suitable methods for solving /or recovering and stabilization of the heavy metals in seawaters, soil and effluents [34].

Conventional methods for removing heavy metals contamination: Numerous clean-up techniques have been suggested and practiced for the removal of heavy metals from the contaminated or pollutant area by using chemical, physical and biological methods. There are several conventional technologies such as precipitation, ion-exchange, electrolytic technologies, chemical extraction, leaching, hydrolysis, polymer micro-encapsulation, and the most common practiced excavation and land filling [35,36]. All of these chemicals methods are posed a serious health and ecological threats due to their toxicity and mutagenicity. Vapour extraction, stabilization, solidification, verifications and membrane technology are previously used for removed the heavy metal ions from pollutant area [36,37].

However, most of these techniques are very expensive for implementation large scale and also dangerous for constant monitoring and control because sometimes it cannot completely remove the heavy metals contaminated. It tend to remove all microbial biota including the useful symbionts such as nitrogen-fixing bacteria as well as other fauna during the process of sanitisation thereby reducing the biodiversity of the area [38]. These techniques may not always be feasible as their nonspecific metals-binding properties [39].

Disadvantages of conventional methods: The high cost of technologies have always used for entirely changing their manufacturing processes or most of the industrialists are not implementing clean-up technologies or replacing their old systems with cleaner, safer and environmental friendly machinery. The use of conventional chemicals for treating heavy metals pollution cannot economically feasible, especially when dealing with low metal-ion concentrations.

According to the Huang et al. [40], several disadvantages in this method can be found. The erratic metal ions removal, high reagent requirements and the generation of toxic sludge are frequently difficult to dewater and need extreme caution in their disposal. Yazdani et al. [41] reported that the conventional methods are expensive especially for handling large amount of water and wastewater contains heavy metals in low concentrations. The needs of several innovative treatment technologies for the removal of heavy metals ions from wastewater are required. Khan et al. [35] suggested that there are possibilities of employing the technology using biological treatments or bioremediation techniques as the alternative methods for removing the heavy metals ions from the contaminated soils or waters.

\section{Bioremediation}

Bioremediation is considered alternative processing methods for removing the heavy metals ions from polluted area. Bioremediation is naturally living organisms to reduce the environmental pollutants into less toxic forms. It is followed by bacteria and fungi or plants to degrade or detoxify hazardous ingredients to human health /or the environment. Huang et al. [40] have defined bioremediation as a process by which organic or inorganic waste biologically degraded or transformed usually to innocuous materials. The process can function naturally or can be enhanced by adding an electron acceptor, nutrient or other factors. The microorganisms may be isolated from an indigenous contaminated area or elsewhere and apply to the contaminated site. Contaminant materials are transformed by living organisms through reactions that take place as a part of their metabolic processes. The use of microbial metabolism process has offered a viable, safer, more efficient and less expensive for cleaning of pollutions.

The principles of the bioremediation can be divided into several techniques that including biofilters, bioventing, biosorption, composting, bioaugmentation, bioreactor, land farming and biostimulation [40]. Khan et al. [35] pointed out that the control and optimization of bioremediation processes are complex factors. These factors include the presence of microbial population proficient of degrading the pollutants, the availability of contaminants to the

\begin{tabular}{|l|l|l|}
\hline Heavy Metals & Sources & Effects and Significance \\
\hline Arsenic & Mining by product, pesticides, chemical waste. & Toxic and possibly carcinogenic. \\
\hline Beryllium & Coal, nuclear power and space industries. & Acute and chronic toxicity. \\
\hline Boron & Coal, detergent formulations, industrial waste. & Toxic to some plants. \\
\hline Chromium & Metal plating, cooling tower water additive. & Essential trace element, possibly carcinogenic as Cr (VI). \\
\hline Iron & Corroded metal, industrial wastes. & Essential nutrient (component of haemoglobin), damages materials. \\
\hline Lead & Industrial sources, mining, plumbing, fuels. & Toxicity, wild destruction. \\
\hline Manganese & Mining, industrial waste, acid mine drainage & Toxic to plants at higher levels. \\
\hline Mercury & Industrial waste, mining, coal. & Acute and chronic toxicity. \\
\hline Molybdenum & Industrial waste, natural sources, cooling-tower water additive. & Toxic to animals, essential for plants. \\
\hline Selenium & Natural geological sources, sulphur, coal. & Essential at low levels, toxic at higher levels, causes 'alkaline disease'. \\
\hline
\end{tabular}

Table 2: Sources and effects of heavy metals in natural water [22]. 
microbial population and the environment factors as like as soil type, temperature, $\mathrm{pH}$, the presence of oxygen or other electron acceptors, and nutrients. Bioremediation are unique method for cleaning the polluted environments from the atmosphere (industrials emissions and soil vent gases), solids (soils, sediments and also sludge), liquids (groundwater, industrial effluents) and raw materials from industrial processing. Living or non-living microorganisms can use their enzymes to accomplish in the task $[36,42]$.

Several researchers have reported that some potential microbes are able to tolerate with heavy metals either they able to remove them from the environments or break them down to less toxic or completely benign forms then utilize in their metabolic processes for growth $[36,42]$. Microbial resistance and tolerance toward pollutants particularly heavy metals are absolutely vital in the bioremediation processes as required microorganisms such as fungi and bacteria that come into closer physical contact with the pollutants due to accomplish the processes and tasks $[43,44]$. Joho et al. [45] have reported that the heavy metals resistance can be divided into two main categories that are:

The accumulation of metal ions can be reduced by the cells because of the elimination of metals chelating substances or by the breakdown of the specific transport system.

Changes in the intracellular distribution of the ions by binding to specific intracellular molecules.

The processes of bioremediations are involved in metalsmicrobe interaction including methods of adsorption, complexation, precipitation, oxidation and reductions. The chemical reactions between microorganisms and metal ions are categorized into six distinct processes $[26,46]$, namely (i) intracellular accumulation, (ii) cell wall associated metals, (iii) extracellular mobilization or immobilization of metals, (iv) metalsiderpohore interactions, (v) extracellular polymermetals interaction with transformation and (vi) volatilization of metals. Kapoor and Viraraghavan [47] indicated that the uptake of heavy metals by the microorganisms could be taken place the toxic ions in several ways in which the bacteria, fungi and algae $[17,48]$. Overview of bioremediation potential for heavy metals contamination through microbe-heavy metals interactions are shown in Table 3.

\section{Biosorption}

Biosorption is an important for researcher to explore microbes from the ecological environment for the use in metal. Lovely [49] is manipulated the microbe-metals interactions including reduction for anaerobic respiration, detoxification, biosorption, bioleaching, bioaccumulation and biomineralization. Biosorption process is extensively studied via microbial biomass as a biosorbent for heavy metal removal.

Biosorption is the process that includes the uses of microbes to detoxify and control the environments pollutants. Based on the interaction between living and non-living microorganisms, and metallic ions in the systems are cleaned up the polluted sites. Accordingly, both living and dead biomass can be entirely employed in biosorptive processes, and it is frequently showed clear tolerance towards metals and other conditions such as low $\mathrm{pH}[17,47,48]$. The combination pathway or genetically modifications of microorganisms have the ability to reduce particular toxic substances.

The use microbial biomass is effectively removed different types of metals ions concentration from aqueous solutions [17,50]. This method is more cost effective and eco-friendly. There are two ways /or mechanisms for microbes in accumulating the heavy metals; biosorption- a metabolism-independent binding of negatively charged free groups to the fungal cell wall, (b) bioaccumulation, an energydependent metal influx [50,51]. As a concern of metal accumulation, microorganisms have developed with different mechanisms of metal resistance, including cell membrane metal efflux [52], intracellular chelation by metallothionein proteins and glutathione-derived-peptides called phytochelatins $[53,54]$ as well as metal compartmentalization in vacuoles [4].

\section{Biosorption Techniques}

The biosorption techniques are independently up taken the biological metabolic cycle. These biosorption technologies are alternatively used several natural materials of biological origins which include bacteria, yeast, fungi, and algae [55]. Shumate and Strandberg [56] have defined biosorption as a 'non-directed physic-chemical interaction that may occur between metal or radio nuclide species and cellular compounds of biological species. Kapoor et al. [57] have defined biosorption as an interaction between living and non-living microorganisms, and metallic ions in the system. On the other hand, biosorption is involved the uses of microbes to detoxify and control environmental impurities, and received attention to clean up polluted sites as well as comprehensively studied using microbial biomass as a biosorbent for heavy metals removals $[17,18]$.

The processes of biological components are involved in living or non-living organisms. These processes are not only required active cell metabolism. There are several types of chemical groups that may be removed by these processes which included compound of heavy metals that have strong electronegative such as hydroxyl, sulfyhryl ions, carboxyl in anionic groups, as well as phosphate group and nitrogen containing group like amino groups. All these groups are played a vital role in the accumulation and the binding of many toxic metals in the non-specific or specific binding sites on the cell membrane of the microbes at which it will absorb and turn these toxins into their cellular structures [58]. Biosorption techniques are offered several advantages due to require low operating cost and high efficiency for removing low concentration of heavy metals from wastewater. This method is helped the metal ions to recover, stabilize or buried back after their physically removed from the environments $[18,36,57]$.

\begin{tabular}{|l|l|l|}
\hline Heavy Metals & Mechanisms of microbe contaminant interactions & Types of contaminant alteration \\
\hline Copper & Sorbs to extracellular polymer and biomass. & Immobilized by sorption process. \\
\hline Nickel & Sorbs to extracellular polymer and biomass. & Immobilized by sorption process. \\
\hline Zinc & Sorbs to extracellular polymer and biomass. & Immobilized by sorption process. \\
\hline Mercury & Enzymatically oxidized, reduced or methylated to promote detoxification. & Volatilized or immobilized by sorption, methylation, and precipitation. \\
\hline Chromium & Enzymatically oxidized or reduced to promote detoxification. & Immobilized by precipitation. \\
\hline Manganese & Sorbs to extracellular polymers and biomass. & Immobilized by sorption; methylation possible. \\
\hline Iron & Sorbs to extracellular polymers and biomass. & Immobilized by sorption; methylation possible. \\
\hline
\end{tabular}

Table 3: Overview of bioremediation potential for heavy metals contamination through microbe-heavy metals interactions [46]. 
Citation: Siddiquee S, Rovina K, Azad SA, Naher L, Suryani S, et al. (2015) Heavy Metal Contaminants Removal from Wastewater Using the Potential Filamentous Fungi Biomass: A Review. J Microb Biochem Technol 7: 384-393. doi:10.4172/1948-5948.1000243

\section{Filamentous Fungi for the Absorption of Heavy Metals and the Future Cleaning-Up Microorganisms}

Filamentous fungi are included as a biosorption agent. It is preferred towards other organisms for the bioremediation due to their ability to remove the concentrated heavy metal ions from liquid substrates. Many fungal species have been reported such as Trichoderma autroviride, $T$. harzianum, T. virens and Aspergillus niger, that are used in the process of cleaning polluted areas $[1,17,18,59,60]$.

The tolerance and capability of detoxify metals are involved numerous mechanisms such as valence transformation, extra and intracellular precipitation and active uptake. Among the above reasons, it is considered as potential alternative synthesis resins for the remediation of dilute solution of metals and solid wastes. It has versatile biosorption group; can grow and work under extreme conditions of $\mathrm{pH}$, temperature and nutrient availability as well as high metal concentrations.

The resistances of the fungi toward heavy metals can define as the ability of organisms are survived metals toxicity by means of mechanism formed in direct response to metal species concerned. Compared to other biosorption agent, fungi biomasses have high percentage of cell wall materials that are involved superb metal binding properties in which it can take considerable quantities of heavy metals even the absence of physiological activity.
Interactions of fungi with metals to detoxify heavy metals ions from the polluted sites may occur through several mechanisms (Figure 1) $[61-63]:$

\section{Mobilization of metals}

This process occurs due to the production and excretion of fungal products such as citric acid, an efficient metal ions chelator and oxalic acid which interact with metal ions to produce insoluble oxalate, resulted from the dissolution of primary metals containing phosphate. These organic acids may increase the metal solubility by means of mycosphere acidification and production of metal-complex structure.

\section{Bio-sorption to cell wall}

Fungal cell wall is the first cellular components that interact with metal species, thus play an important roles as a protective layer and barrier that control the uptake of potentially toxic metals into the cell. Interaction of metal with fungal cell wall involves a complex mechanism which includes several processes such as ion exchange, complexation, crystallization, adsorption and precipitation and also influenced by the biomass concentration and chemical behaviour of the metals.

\section{Metal uptake}

Specific transporters are responsible or the uptake of essential metals. These transporters are possible to react with other type of metals. Carriers may consist of all the metabolically-coupled and $\mathrm{H}^{+}-$ gradient driven transport system.

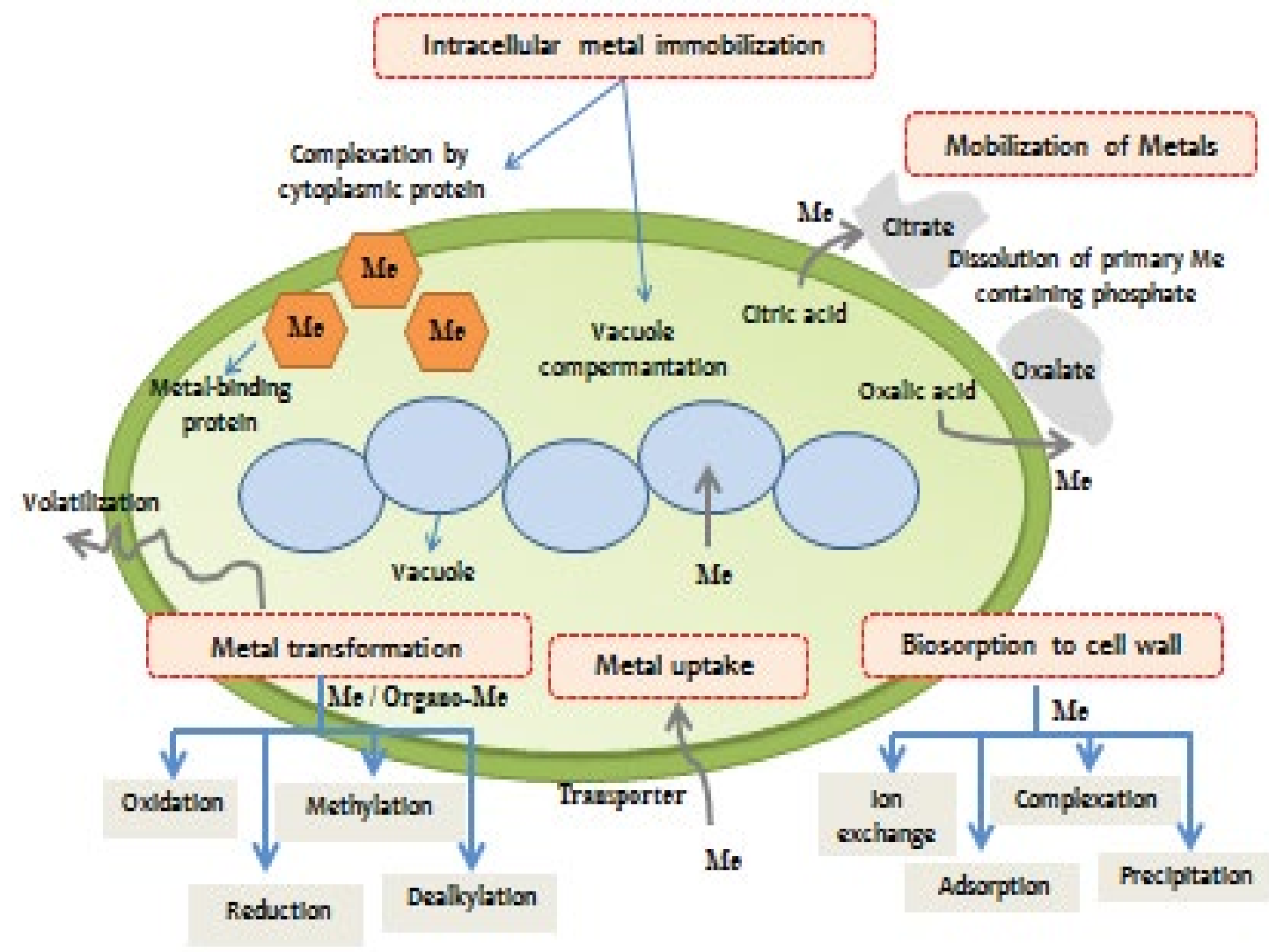

Figure 1: Schematic of fungi-metal interactions (Adapted from [61-63]). 


\section{Intracellular metal immobilization}

Intracellular metal immobilization involves two processes that is vacuoles compartmentation and complexation by cytoplasmic protein, called metallothioneins and phytochelatins, a rich SH peptide. Fungal vacuole plays important roles in molecular degradation, storage of metabolites, regulation of cytosolic concentrations of metal ions and detoxifies potentially toxic metal ions. Metallothioneins is a metalbinding protein that can modulate the intracellular concentrations and bind both the essential metal such as $\mathrm{Cu}$ and $\mathrm{Zn}$ and inessential metal such as Cd.

\section{Metal transformations}

Fungi can facilitate biotransformation of metals through chemical reactions such as oxidation, reduction, methylation and dealkylation. These reactions may lead to metal volatilization and reduce the metal toxicity. Metals may also transfer to the other parts of the fungi mycelium and plant symbionts by cytosplasmic vesicles and vacuoles.

Kapoor et al. [57] have stated that living and dead cells of fungi are capable to eliminate the heavy metals ions from aqueous solutions. Fungal microorganisms are uptaken the heavy metals ions and offered an alternative method for their removal metals from wastewater. The fungal biomass is easier and cheaper than the removal of heavy metals pollutant by the conventional or traditional adsorbent techniques using activated carbon, coal or ion exchange [36]. Continuously increasing in the used of fungal in numerous biotechnological processes are widely recognized especially in fermentation and bioremediation industries which are included the production of antibiotics, enzymes and industrial acids.

Fungi are used in several industrial fermentation processes because it can serve as an economical and nonstop supplying biomass for removing the metals ions in polluted areas [47]. The ability of the fungi is simply grown in considerable amounts using unsophisticated fermentation techniques and inexpensive growth media. Some researcher are informed that the metal uptake mechanisms of freeliving fungi are involved three distinct processes which are included the extracellular uptake through an ion exchange process, intracellular accumulation and the trapping of particulates rich in metals contents $[1,41]$.

Siddiquee et al. [60] found good agents for biosorption of heavy metal ions using isolates of Trichoderma autroviride, $T$. harzianum, and T. virens. The selected strains of fungi are potential candidate in the research area due to its frequent presence in high polluted area [1,41]. Filipovic et al. [64] used Aspergillus niger strain and found better biosorption capabilities with different heavy metals ions of $\mathrm{Cu}^{2+}, \mathrm{Zn}^{2+}$, and $\mathrm{Ni}^{+2}$, at $\mathrm{pH}$ ranging from 4 to 6 . In similar studies done by Michael et al. [39] and reported that A. niger is able to grow on culture plates amended with heavy metals and showed five times better inhibition than the growth of yeast. So Aspergillus niger biomass has showed the removal of heavy metals in orderly $70 \%$ for $\mathrm{Zn}$ and $91 \%$ for $\mathrm{Cu}$ from the wastewater.

Siddiquee et al. [60] mentioned that the resistance levels of different concentrations of heavy metals are diverse because the uses different strains of filamentous fungi of $T$. aureoviride, T. harzianum, and $T$. virens. Based on their results, the T. virens strain T128 gave the highest tolerance ability for $\mathrm{Ni}^{3+}$ and $\mathrm{Pb}^{2+}$ in a $1200 \mathrm{mg} / \mathrm{L}$ concentration. The accumulation and uptake capacity is determined by the maximum removal of $\mathrm{Pb}^{2+}, \mathrm{Cu}^{2+}$, and $\mathrm{Ni}^{3+}$ by a $T$. harzianum in liquid medium compared to other fungi. The metal removal occurred of $13.48 \mathrm{~g} / \mathrm{g}$ for
$\mathrm{Pb}^{2+}, 3.1254 \mathrm{~g} / \mathrm{g}$ for $\mathrm{Cu}^{2+}$ and $0.8351 \mathrm{~g} / \mathrm{g}$ for $\mathrm{Ni}^{3+}$, respectively. For $\mathrm{Zn}^{2+}$, the highest tolerance and uptake capacity of metal is recorded at 3.1789 $\mathrm{g} / \mathrm{g}$ by $T$. virens. The mycelium of Rhizopus is an excellent biosorbent towards lead, cadmium, copper, zinc and uranium [4]. Mucorales species is described as good biosorbents [65] and Fusarium flocciferum is used to remove cadmium and nickel from industrial effluents [66].

Karcprzak and Malina [59] have stated that filamentous fungi have the capacity to form chemical complexes between the metal ions and extracellular enzymes, besides the ability to bind the metals ions to their cell walls. Fungi are accumulated broad range of metals such as $\mathrm{Pb}, \mathrm{Cd}, \mathrm{Cu}, \mathrm{Zn}$, and $\mathrm{Ni}$. Due to the composition of their cell walls that are obtained of polysaccharides, protein and lipids are accumulated substantial amounts of metals, so, they can provide an array of binding sites for metals ions.

Fungal cell walls and their components are played a key role in biosorption process. Kapoor et al. [57] have reported that the high volume of the microorganisms and their ability of detoxify metals among the fungi are considered as the potential alternative synthetic resins for removing the diluted solutions of metals and solid wastes. However, it is not only the cleaning process but also protect the environments and biodiversity as well as allowing for the recovery of the metals and their subsequent reuses $[3,36,67]$.

Fungi have a versatile group, for example they can adapt and grow under varying conditions of $\mathrm{pH}$, temperature and nutrient availability as well as at high metals concentration $[36,41,68]$. Fungi are one of the most appropriate organisms used to bioremediation. Because, they can tolerate varies environmental and toxic conditions such as a higher concentration of metals levels, and lower $\mathrm{pH}$ condition also. They have the ability and capacity to bind with heavy metals to their cell walls which are enhanced the intracellular accumulation of those toxins. Consequently, the response of these microorganisms towards toxic heavy metals concentrations are an important due to their interest in the reclamation of contaminated areas. The ability of selected fungi strains towards remediation of heavy metals ions are evaluated by characterizing the bioaccumulations of these metals.

\section{Tolerance of Selected Heavy Metals by Trichoderma sp}

Many past researches on the tolerance and biosorption involving characterization and identification of heavy metals resistant fungi have been carried out (Table 4). Screening and identification of metal resistant fungi can be done by fine methodology for tolerance of the fungal isolates towards the heavy metals. It can be measured as minimum inhibitory concentration (MIC) which indicates the lowest concentration of metal that can prevent growth of the isolate. The MIC can be determined based on the biomass dry weight (\%). The fungi biomass growth pattern represents the adaptation of the fungi to the heavy metals in which the growth will be reduced as the metal concentration increases [69].

Most of the Trichoderma species have high ability of the resistance and tolerate with heavy metals $[17,59,60]$. As reported by Townsley and Ross [70,71] and Townsley et al. [72], T. viride has showed the similar uptake pattern with Aspergillus niger and Penicillium spinulosum. This fungal is able to remove varying heavy metals from aqueous solution through ion-exchange reaction uptake. Studies done by Townsley et al. [73] and Ross and Townsley [74] found that copper, gold, zinc, cadmium and manganese are able to remove the heavy metals ion by fungi. They are found very impressive results with an average of $90 \%$ of heavy metals uptake achieved within 10 minutes by fungal cell. The 
Citation: Siddiquee S, Rovina K, Azad SA, Naher L, Suryani S, et al. (2015) Heavy Metal Contaminants Removal from Wastewater Using the Potential Filamentous Fungi Biomass: A Review. J Microb Biochem Technol 7: 384-393. doi:10.4172/1948-5948.1000243

\begin{tabular}{|c|c|c|c|}
\hline Fungi & Heavy Metals Resistant & Area & References \\
\hline Trichoderma atroviride & Copper, Zinc, Cadmium & Sewage Sludge, Madrid, Spain & [1] \\
\hline Trichoderma atroviride, Mortierellaexigua & Zinc, Barium, Iron & Tarnowskie Gory, South Poland & [59] \\
\hline $\begin{array}{l}\text { Aspergillus niger, Penicillum, alternaria, Rhizopus, Monilia, } \\
\text { Trichoderma }\end{array}$ & $\begin{array}{l}\text { Aspergillus, Penicillum, Geotrichum Alternaria, } \\
\text { Fusarium, Rhizopus, Monilia, Trichoderma }\end{array}$ & Aligarh, Uttar Pradesh, India & [17] \\
\hline $\begin{array}{l}\text { Aspergillus niger, Trichoderma asperellum, Penicillum } \\
\text { simplicissimum }\end{array}$ & Copper, Lead & Langat River, Selangor, Malaysia & [18] \\
\hline Trichoderma atroviride & Zinc & Serdang Industrial Area, Selangor & [41] \\
\hline Trichoderma viride, Aspergillus niger, Penicillium spinulosum & & & [66-68] \\
\hline $\begin{array}{l}\text { Trichoderma viride, Aspergillus oryzae, Aspergillus niger, } \\
\text { Mucor racemosus, Penicillium chrysogenum }\end{array}$ & & & {$[72,73]$} \\
\hline $\begin{array}{l}\text { Trichoderma, Aspergillus, Mortierella, Apecilomyces, } \\
\text { Penicillium, Pythium and Rhizopus }\end{array}$ & Cobalt & Serpentine soil of Andaman & [74] \\
\hline Trichoderma atroviride & Copper, Zinc, Cadmium & Madrid & [87] \\
\hline Trichoderma (FA-06) & Arsenic & West Bengal, India & [79] \\
\hline Trichoderma atroviride strains F6 & Cadmium, Nickel & Unspecified & {$[80]$} \\
\hline T. harzianum, F. phyllophilum & Zinc, Plumbum & Sicily, Italy & [81] \\
\hline T. virens (PDR-28) & Arsenic, Copper, Cadmium, Nickel, Plumbum, Zinc & Mine tailing soil, South Korea & [82] \\
\hline
\end{tabular}

Table 4: Trichoderma sp. their metal of tolerance based on past researches.

metal accumulations of growing cells are varied within the cell age. Maximum metal uptake during the lag phase or known as early stages of growth and declined as cultures reached a stationary phase.

During the biosorption processes are changed in $\mathrm{pH}$ recorded. $\mathrm{pH}$ is dropped during the growth and the reduction in metal-uptake pattern. In addition, the changes in cell wall composition with growth and the release of metabolites that are binder with the metal ions during the constant $\mathrm{pH}$ recorded [73,74]. Huang et al. [75] have recorded the biosorption of cadmium $(\mathrm{Cd})$ on various fungal strains are $\mathrm{pH}$ very sensitive. Some fungal strains have a better biosoprtion capacity in the acidic range.

Trichoderma viride has showed higher amount cadmium uptaken at lower concentration of biomass comparing to A. oryzae, A. niger, Mucor racemosus and P. chrysogenum [76,77]. The higher biomass concentrations can be attributed to the electrostatics interactions of the functional groups at the cell surfaces. Higher concentrations in cell suspensions are attached each other and thus lower the cell surface area in contact with the solution. The growth conditions can affect the metal uptake of the biomass. Trichoderma fungi have diverse metabolic adaptability and showed several heavy metals resistance [78]. Several filamentous fungi (Aspergillus, Mortierella, Apecilomyces, Penicillium, Pythium and Rhizopus) are isolated from serpentine soil of Andaman for cobalt resistance. All of these fungi from metalpercoalted environment are similarly efficient in biosorbing Co (II) ions.

Lopez and Vazquez [1] have reported that T. atroviride strain isolated from sewage sludge water treatment plant in Madrid. It has ability to survive in high metal concentrations as the natural selection of resistant cells. In vitro assays, T. atroviride is confirmed a high tolerance against copper, zinc and cadmium. Microorganisms isolated from natural contaminated with heavy metals environments are found high tolerance adaptation of multiple environmental conditions [79]. The responses of micro-organisms may differ from their response to individual metals or/ multiple metals and additive, synergistic or antagonist interactions may occur between metals [80]. Combinations of several ions are affected based on the metal uptake. The selective accumulations of heavy metals by microorganisms are determined by interionic competition in which metal cations compete for the binding sites on the cell wall $[69,81,82]$. Metal uptake has assayed through by the fungus is cultured in the existing of a single metal and in the presence of a combination of two or three cations, where additive and synergistic interactions are observed. Combinations of zinc, copper and cadmium are assayed as single metals $(50 \mathrm{mg} / \mathrm{ml})$ moderately inhibited the growth of T. atroviride.

Trichoderma has found among the other fungi with highest arsenic effectively removal from arsenic contaminated agricultural soils [83]. Arsenic is a toxic compound which existed in inorganic and organic forms. Different strains have different ability in bioindicators of arsenic pollution. Trichoderma strain FA-06 is able to sporulate well on the arsenate exposure as compared to control and other Trichoderma strains [84]. Some Trichoderma strains have showed a decrease in $\mathrm{pH}$ ranging from 12.03 to $18.05 \%$ and 24.08 to $34.24 \%$ in arsenic treatment (Figure 2 and 3). They have concluded that Trichoderma is the best capability in biovolatilizing arsenic and efficient in removing arsenic from liquid medium by $56.12 \%$. T. atroviride strain F6 significantly alleviated the cellular toxicity of cadmium and nickel to plants [84]. Inoculations of B. juncea (L.) Coss. var. foliosa with T. atroviride strain F6 have showed the increase in fresh weight in Cd for $110 \%$, Ni for $40 \%$ and $\mathrm{Cd}-\mathrm{Ni}$ for $170 \%$, contaminated soils, respectively $(\mathrm{P}<0.05)$. The translocation factors and metal bioconcentration factors are calculated for the inoculated plant increased comparing to the non-inoculated plants. The results are indicated that the efficiency of phytoextraction for B. juncea (L.) Coss. var. foliosa has enhanced after inoculating with $T$. atroviride strain $\mathrm{F} 6$. The fungal treated plants grown in $\mathrm{Cd}-\mathrm{Ni}$ combination contaminated soils are showed higher phytoextraction efficiency than those in Cd or Ni contaminated soils. So, it is suggested that the fungus T. atroviride strain $\mathrm{F} 6$ endowed with organic-degrading capabilities could be exploited for fungi-assisted phytoremediation of mixed organic-metal contaminated soils.

Four different types of fungal have ability on growing in the presence of heavy metals and monitored their cysteine and glutathione content and the activity of $O$-acetylserine (thiol) lyase (OASTL) which is involved in cysteine biosynthesis studies [85]. They have found that the presences of $\mathrm{Zn}$ and $\mathrm{Pb}$ have not affect the fungal growth or sporulation at the concentration used of 5 and $10 \mathrm{ppm}$. Cysteine and glutathione contents are always higher when fungi are grown in the presence of toxic metals. As T. harzianum and F. phyllophilum are showed the best growth rate on $\mathrm{Cd}$ and $\mathrm{Hg}$. T. harzianum and F. pyyllophilum have grown in the presence of $\mathrm{Zn}, \mathrm{Pb}, \mathrm{Cd}$, and $\mathrm{Hg}$ and accumulated high amounts of these metals when metal-containing media. 


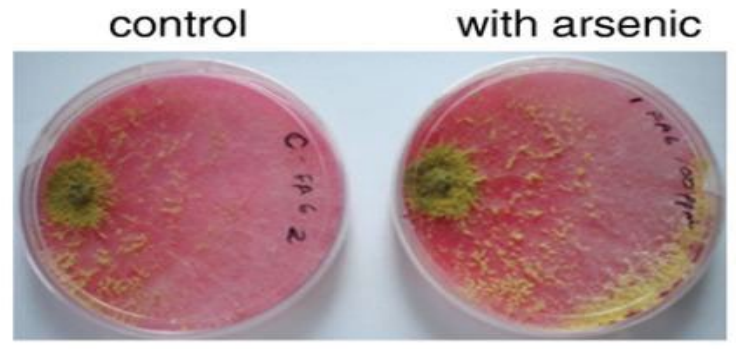

Trichoderma spp.(FA-06) showing increased sporulation

Figure 2: Morphological variation in Trichoderma (FA 06) strains in arsenic treated and control media plates [79].

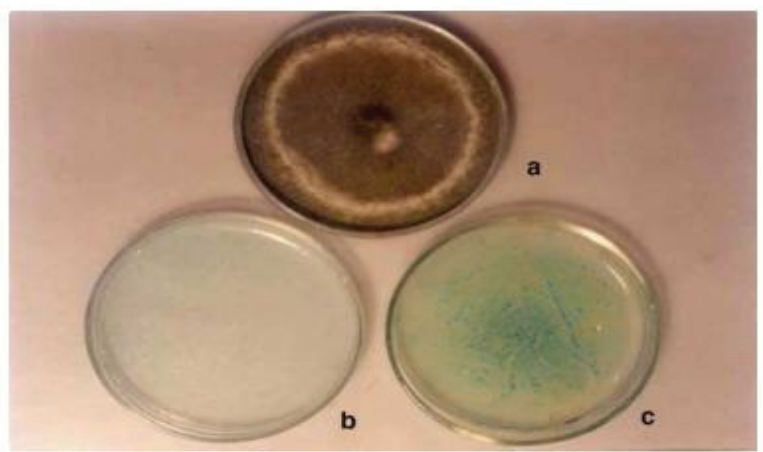

Figure 3: Precipitation of copper on solid medium; (a) Control (without metal), (b) uninoculated plate containing copper and (c) Copper Precipitation with $100 \%$ growth at $3000 \mathrm{mg} / \mathrm{L}[65]$.

Babu et al. [86] have successfully isolated T. virens named PDR28 and found MICs for $1300 \mathrm{mg}$ of As, $1000 \mathrm{mg}$ of $\mathrm{Cu}, 1300 \mathrm{mg}$ of $\mathrm{Cd}, 700 \mathrm{mg}$ of $\mathrm{Ni}, 2500 \mathrm{mg}$ of $\mathrm{Pb}$ and $3100 \mathrm{mg}$ of $\mathrm{Zn}$ have indicated the heavy metal adaptation stress; differences in tolerance may reflect different adaptation strategies or mechanisms involving permeability barriers, intra and extracellular sequestration, efflux pumps, enzymatic detoxification, and metal speciation. Anand et al. [68] and Iskandar et al. [18] have identified T. asperellum and T. viride at heavy metal contaminated sites. Strain PDR-28 effectively removed heavy metals in the order of $\mathrm{Pb}>\mathrm{Cd}>\mathrm{As}>\mathrm{Zn}>\mathrm{Cu}$ from liquid media containing 100 mg heavy metals $\mathrm{L}^{-1}$. Strain PDR-28 may be more effective heavy metal biosorbent at contaminated sites and in industrial wastewater. Several strains of Trichoderma such as T. atroviride, T. harizianum, and $T$. viride have been used for removing heavy metals from aqueous solution $[18,60,68]$.

Trichoderma viride is tolerated of $500 \mathrm{mg} \mathrm{Cu} \mathrm{L}^{-1}$ in modified Czapex Dox minimal agar medium reported by Anand et al. [68]. In agar medium, effect of $1000-5000 \mathrm{mg} / \mathrm{L}$ of $\mathrm{Cu}(\mathrm{II})$ are tested and the results found of $100 \%$ growth of $T$. viride upto the concentration of $3000 \mathrm{mg} / \mathrm{L}$ against control (Figure 2). Similar level of tolerance reported by Tsekova and Todorova [87] by using $A$. niger B-77 strain where $300 \mathrm{mg} / \mathrm{L}$ of $\mathrm{Cu}(\mathrm{II})$ ion is inhibitory to the growth of the organism. The mycelia turned blue both on agar media and in broth culture at all concentrations of copper, which is the binding of $\mathrm{Cu}$ (II) to the fungal cell wall. Blue coloured mycelia reported by Subramanyam and
Gupta [88] and Venkateswerlu et al. [89] in the presence of copper in Neurospora crassa and Cunninghamella blackesleeana, respectively. They suggested that the blue color of the mycelia is binded of $\mathrm{Cu}$ (II) with cell wall protein of the mycelium. Interestingly, $81.78 \%$ of the $\mathrm{Cu}$ (II) removal is observed at a copper concentration of $100 \mathrm{mg} / \mathrm{L}$ in 72 h. Gadd and Griffiths [90,91] and Townsley and Ross [70] have reported the maximal copper uptake in lag phase in Aureobasidium pullulans and A. niger, respectively.

Iskandar et al. [18] have used four strains of fungus, namely, $A$. niger, A. fumigatus, T. asperellum, and Penicillium simplicissimum. T. asperellum has able to tolerate with $800 \mathrm{mg} \mathrm{Cu} \mathrm{L}^{-1}$ and $1000 \mathrm{mg} \mathrm{Pb}$ $\mathrm{L}^{-1}$ in PDA medium, showing a better uptake capacity for $\mathrm{Pb}$. This result indicated that T. asperellum is a promising biosorptive agent. Among the filamentous fungi of Aspergillus, Penicillum, Geotrichum Alternaria, Fusarium, Rhizopus, Monilia and Trichoderma are identified in soil previously reported by Zafar et al. [17]. All strains are tested for the Cobalt, chromium, copper, cadmium and nickel. Trichoderma is showed MIC of heavy metals of the average of 6 to 3 $\mathrm{mg} \mathrm{ml}^{-1}$.

The exposure of fungi on zinc resistance with different concentrations between $0-6000 \mathrm{mg} / \mathrm{L}$ has conducted by Yazdani et al. [41]. Among 30 isolates fungi cultured, only T. atroviride is found able to grow at $6000 \mathrm{mg} / \mathrm{L}$ of zinc concentration on PDA. Accordingly, T. atroviride is the highest tolerance towards $\mathrm{Zn}$. Uptake capacity of T. atroviride is ranged from $18.1-26.7 \mathrm{mg} / \mathrm{g}$ in liquid media at $\mathrm{Zn}$ concentrations from $500-1000 \mathrm{mg} / \mathrm{L}$. T. atroviride showed of $47.6-$ $64 \%$ adsorption in liquid media and $30.4-45.1 \%$ of absorption for $\mathrm{Zn}$. Based on this study, 5.7-7.4\% of $\mathrm{Zn}$ removal is observed due to biomass washing. The high adsorption, relatively low absorption and high uptake capacity of $\mathrm{Zn}$ suggested that $T$. atroviride is a potential bioremediator of $\mathrm{Zn}$. This result has proven that the filamentous fungi isolated from soil contaminated heavy metals sites have more potential strains comparing to other located isolates fungi and it can be exploited for removing heavy metal ions from aqueous solution.

\section{Conclusion}

Interest in processes involving heavy metal uptake by microorganisms has increased considerably in recent years due to the biotechnological potential of micro-organisms in removing and/or recovery of metals. The conventional methods such as synthetic ion exchangers are considered as mature technologies. Biosorption is still in its developmental stages, and additional improvements in both performance and costs can be expected. Based on the previous research on the capability of Trichoderma sp. in removing heavy metals, it is completely suggested that Trichoderma sp. should be considered as the agents in bioremediation process.

\section{References}

1. López Errasquín E, Vázquez C (2003) Tolerance and uptake of heavy metals by Trichoderma atroviride isolated from sludge. Chemosphere 50: 137-143.

2. Dedyukhina EG, Eroshin VK (1991) Essential metal ions in the control of microbial metabolism. Proc Biochem 26: 31-37.

3. Gadd GM (1986) Fungal responses towards heavy metals. In: Herbert RA Codd GA, Microbes in Extreme Environments. Academic Press, London.

4. Volesky B (1994) Advances in biosorption of metals: selection of biomass types. FEMS Microbiol Rev 14: 291-302.

5. Domenech X (1998) Quimica Ambiental El Impacto Ambiental de los Residous. Miraguano Ediciones, Madrid.

6. Price MS, Classen JJ, Payne GA (2001) Aspergillus niger absorbs copper and zinc from swine wastewater. Bioresour Technol 77: 41-49. 
Citation: Siddiquee S, Rovina K, Azad SA, Naher L, Suryani S, et al. (2015) Heavy Metal Contaminants Removal from Wastewater Using the Potential Filamentous Fungi Biomass: A Review. J Microb Biochem Technol 7: 384-393. doi:10.4172/1948-5948.1000243

7. Cochrane WW (1958) Farm Prices: Myth and Reality. St paul. University of Minnesota Press.

8. Williams J, Clarkson JM, Mills PR, Cooper RM (2003) A selective medium for quantitative reisolation of Trichoderma harzianum from Agaricus bisporus compost. Appl Environ Microbiol 69: 4190-4191.

9. Harman GE, Howell CR, Viterbo A, Chet I, Lorito M (2004) Trichoderma species--opportunistic, avirulent plant symbionts. Nat Rev Microbiol 2: 43-56.

10. Benítez T, Rincón AM, Limón MC, Codón AC (2004) Biocontrol mechanisms of Trichoderma strains. Int Microbiol 7: 249-260.

11. Kredics L, Antal Z, Manczinger L, Nagy E (2001) Breeding of mycoparasitic Trichoderma strains for heavy metal resistance. Lett Appl Microbiol 33: 112-116.

12. Kredics $L$, Doczi I, Antal Z, Manczinger $L$ (2001) Isolation and characterization of heavy metal resistant mutants from mycoprasitic Trichoderma strains. Biol. Cont. Fungal Bacterial Plant Pathogens. IOBC wprs Bulletin 24: 233-236.

13. Radojevic M, Abdullah MH, Aris AZ (2007) Analisis Air. Scholar Press, Selangor.

14. Yu MH (2001) Environment Toxicology: Impacts of Environmental Toxicants on Living Systems. ( $3^{\text {rd }}$ Edn)CRS Press LLC, Florida.

15. Forstner U, Wittmann GTW (1983) Metal Pollution in the Aquatic Environment $\left(2^{\text {nd }}\right.$ Edn), Springer- Verlag, Berlin.

16. Poli A, Salerno A, Laezza G, di Donato P, Dumontet S, et al. (2009) Heavy metal resistance of some thermophiles: potential use of alpha-amylase from Anoxybacillus amylolyticus as a microbial enzymatic bioassay. Res Microbiol 160: 99-106.

17. Zafar S, Aqil F, Ahmad I (2007) Metal tolerance and biosorption potential of filamentous fungi isolated from metal contaminated agricultural soil. Bioresour Technol 98: 2557-2561.

18. Iskandar NL, Zainudin NA, Tan SG (2011) Tolerance and biosorption of copper $\mathrm{(Cu})$ and lead $(\mathrm{Pb})$ by filamentous fungi isolated from a freshwater ecosystem. J Environ Sci (China) 23: 824-830

19. Arora M, Kiran B, Rani S, Rani A, Kaur B, et al. (2008) Heavy Metals accumulation in vegetables irrigated with water from different sources. Food Chem 111: 811-815.

20. Hardman DJ, McEldowney S, Waite S (1993) Pollution: Ecology and Biotreatment. Longman Scientific and Technical, England.

21. Mengel K, Kirkby EA (1979) Principle of Plant Nutrition (2nd Ed) Internationa Potash Institute Berne, Switzerland.

22. Manahan SE (1997) Environmental Science and Technology, Lewis Publishers, New York.

23. Radhika V, Subramanian S, Natarajan KA (2006) Bioremediation of zinc using Desulfotomaculum nigrificans: bioprecipitation and characterization studies. Water Res 40: 3628-3636.

24. Fosmire GJ (1990) Zinc toxicity. Am J Clin Nutr 51: 225-227.

25. Chang R (2005) Chemistry, (4 $4^{\text {th }}$ Edn) McGrawhill, New York.

26. Davies DJA, Bennett BG (1983) Exposure Commitment Assessment of Environment pollutants Vol. 3 MARC (Monitoring and Assessment Research Centre) Report Number 30 MARC Publication, London.

27. Batey T, Berryman C, Line C (1972) The Disposal of Copper- Enriched Pig Manure Slurry on Grassland. J Br Grassland Social 27: 139-143.

28. Lee KS (2003) Kajian Kepekatan Logam Berat Kuprum and Zink dalam sedimen Sungai Kimanis, Sabah.

29. Handy RD (2003) Chronic effects of copper exposure versus endocrine toxicity: two sides of the same toxicological process? Comp Biochem Physiol A Mol Integr Physiol 135: 25-38.

30. Insel P, Elainturner R, Ross D (2004) Nutrition, (2nd Edn) American Dietetic Association, New York.

31. Dunnick JK, Elwell MR, Radovsky AE, Benson JM, Hanh FF, et al (1995) Comparative Carcinogenic Effects of Nickel Subsulfide, Nickel Oxide or Nickel Sulphate Hexahydrate Chronic Exposure in the Lung. Cancer Res 55: 5251-5256.

32. Crosby DG (1998) Environmental Toxicology and Chemistry Oxford University Press, New York.

33. Blackmore R, Reddish A (1996) Global Environmental Issues Hodder and
Stoughton, United Kingdom.

34. Sani RK, Peyton BM, Brown LT (2001) Copper-induced inhibition of growth of Desulfovibrio desulfuricans G20: assessment of its toxicity and correlation with those of zinc and lead. Appl Environ Microbiol 67: 4765-4772.

35. Khan AG, Bari A, Chaudhry TM, Qazilbash AA (1997) PhytoremediationStrategy to Decontaminate Heavy Metal Polluted Soils and to Conserve the Biodiversity of Pakistan Soils. In: Mufti SA, Woods CA, Hasan SA, Biodiversity of Pakistan Pakistan Museum of Natural History, Islamabad and Florida Museum of Natural History, Gainesville, Florida.

36. Qazilbash AA (2004) Isolation and Characterization of Heavy Metal Toleran Biota from Industrially Polluted Soils and Their Role in Bioremediation. Biological Sci 41: 210-256.

37. Balba MT, Al-Awadhi N, Al-Daher R (1998) Bioremediation of oil- contaminated soil: microbiological methods for feasibility assessment and ? eld evaluation. J Microbiol Meth 3: 155-164.

38. Chaudhry TM, Hill L, Khan AG (1999) Bioremediation of Iron and Zinc contaminated dumped filter cake by microbes, plants and associated mycorrhizae. In: Wong M, Bakar AJM, Bioremediation of heavy metals, CRC Press, Boca Raton, Florida.

39. Price MS, Classen JJ, Payne GA (2001) Aspergillus niger absorbs copper and zinc from swine wastewater. Bioresour Technol 77: 41-49.

40. Huang JP, Huang CP, Morehart AL (1991) Removal of heavy metals by fungal (Aspergillus oryzae) adsorption, In: Vernet JP, Heavy Metals in the Environment, Elsevier, London.

41. Yazdani M, Chee KY, Faridah A, Soon GT (2010) An in vitro study on the Adsorption, Absorption and uptake Capacity of $\mathrm{Zn}$ by the Bioremediator Trichoderma atroviride. Environ Asia 3: 53-59.

42. Atlas RM, Unterman R (1999) Bioremediation in Manual of Industria Microbiology and Biotechnology, 2nd American Society for Microbiology Press, Washington DC.

43. Parales RE, Ditty JL, Harwood CS (2000) Toluene-degrading bacteria are chemotactic towards the environmental pollutants benzene, toluene, and trichloroethylene. Appl Environ Microbiol 66: 4098-4104

44. Sharma PK, Balkwill DL, Frenkel A, Vairavamurthy MA (2000) A new Klebsiella planticola strain ( $\mathrm{Cd}-1)$ grows anaerobically at high cadmium concentrations and precipitates cadmium sulphide. Appl Environ Microb 66: 3083-3087.

45. Joho M, Inouhe M, Tohoyama H, Murayama T (1995) Nickel resistance mechanisms in yeasts and other fungi. J Ind Microbiol 14: 164-168.

46. Ford T, Mitchell M (1992) Microbial Transport of Toxic Metals: Environmental Microbiology. John Wiley and Sons, New York.

47. Kapoor A, Viraraghavan T (1998) Biosorption of heavy-metal on Aspergillus niger: e?ect of pretreatment. Biores Technol 63: 109-113

48. Gadd GM (1990) Fungi and yeast metal accumulation: Microbial Minera Recovery, McGraw-Hill, New York.

49. Lovley DR, Phillips EJ (1994) Reduction of Chromate by Desulfovibrio vulgaris and Its c(3) Cytochrome. Appl Environ Microbiol 60: 726-728.

50. Gomes NCM, Mendonca-Hagler L, Savvaidis I (1998) Metal bioremediation by microorganisms. Rev Microbiol 29: 85-92.

51. Cervantes C, Gutierrez-Corona F (1994) Copper resistance mechanisms in bacteria and fungi. FEMS Microbiol Rev 14: 121-137.

52. Kamizono A, Nishizawa M, Teranishi Y, Murata K, Kimura A (1989) Identification of a gene conferring resistance to zinc and cadmium ions in the yeast Saccharomyces cerevisiae. Mol Gen Genet 219: 161-167.

53. Kneer R, Kutchan TM, Hochberger A, Zenk MH (1992) Saccharomyces cerevisiae and Neurospora crassa contain heavy metal sequestering phytochelatin. Arch Microbiol 157: 305-310.

54. Presta A, Stillman MJ (1997) Incorporation of copper into the yeast Saccharomyces cerevisiae. Identification of $\mathrm{Cu}(\mathrm{I})$--metallothionein in intact yeast cells. J Inorg Biochem 66: 231-240.

55. BayramoÄŸlu G, BektaÅŸ S, Arica MY (2003) Biosorption of heavy metal ions on immobilized white-rot fungus Trametes versicolor. J Hazard Mater 101: 285-300.

56. Shumate ES, Strandberg WG (1985) Accumulation of metals by microbial cells Comprehensive Biotechnol 13: 235-247. 
Citation: Siddiquee S, Rovina K, Azad SA, Naher L, Suryani S, et al. (2015) Heavy Metal Contaminants Removal from Wastewater Using the Potential Filamentous Fungi Biomass: A Review. J Microb Biochem Technol 7: 384-393. doi:10.4172/1948-5948.1000243

57. Kapoor A, Viraraghavan T, Cullimore DR (1999) Removal of heavy metals using fungus Aspergillus niger. Biores Technol 70: 95-104.

58. Tobin JM, Cooper DG, Neufeld RJ (1984) Uptake of Metal lons by Rhizopus arrhizus Biomass. Appl Environ Microbiol 47: 821-824.

59. Karcprzak M, Malina G (2005) The tolerance and Zn2+, Ba2+ and Fe2+ accumulation by Trichoderma atroviride and Mortierella exigua isolated from contaminated soil. Can J Soil Sci 85: 283-290.

60. Siddiquee S, Aishah SN, Azad SA, Shafawati SN, Naher L (2013) Tolerance and Biosorption capacity of $\mathrm{Zn} 2+, \mathrm{Pb} 2+, \mathrm{Ni} 3+$ and $\mathrm{Cu} 2+$ by filamentous fungi (Trichoderma harzianum, T. aureoviride and T. virens). Adv Biosci Biotechnol 4: 570-583.

61. Harms H, Schlosser D, Wick LY (2011) Untapped potential: exploiting fungi in bioremediation of hazardous chemicals. Nat Rev Microbiol 9: 177-192.

62. Valls M, de Lorenzo V (2002) Exploiting the genetic and biochemical capacities of bacteria for the remediation of heavy metal pollution. FEMS Microbiol Rev 26: 327-338

63. Gadd GM (1993) Interactions of fungi with toxic metals. New Phytol 124: 25-60.

64. Filipovic KZ, Sipos L, Briski F (2000) Biosorption of chromium, copper, nicke and zinc ions onto fungal pellets of Aspergillus niger from aqueous solutions. Food Technol Biotechnol 38: 211-216.

65. Remacle J (1990) The cell wall and heavy metals. In: Volesky B, Biosorption of Heavy Metals, CRC Press, Boca Raton, Florida.

66. Delgado A, Anselmo AM, Novais JM (1998) Heavy metal biosorption by dried powdered mycelium of Fusarium flocciferum. Water Environ Res 70: 370-375.

67. Brierley CL, Brierley JA (1993) Immbilization of Biomass for Industrial Application of Biosorption. In: Torma AE, Apel ML, Brierley CL, Warrendale PA Biohyrometallurgy Technologies, the Minerals, Metals and Materials Society.

68. Anand P, Isar J, Saran S, Saxena RK (2006) Bioaccumulation of copper by Trichoderma viride. Bioresour Technol 97: 1018-1025.

69. Lairini K, Ezzouhri L, Castro E, Moya, and Espinola F( 2009) Heavy metal tolerance of filamentous fungi isolated from polluted sites in Tangier, Morocco. African J of Microbiol Res 3: 35-48.

70. Townsley CC, Ross IS (1985) Copper uptake by Penicillium spinulosum. Microbios 44: 125-132.

71. Townsley CC, Ross IS (1986a) Copper uptake in Aspergillus niger during batch growth and in non-growing mycelia suspensions. Experimental Mycol 10: 281 288

72. Townsley CC, Ross IS, Atkins AS (1986b) Copper removal from a simulated leach effluent using the filamentous fungus Trichoderma viride. In: Eccles $\mathrm{HH}$, Hunt S, Immobilization of Ions by Biosorption. Ellis Horwood, Chichester, UK.

73. Townsley CC, Ross IS, Atkins AS (1986) Biorecovery of metallic residues from various industrial e?uents using ?lamentous fungi. In: Lawrence RW, Branion RMR, Ebner HG, Fundamental and Applied Biohydrometallurgy. Elsevier, Amsterdam.

74. Ross IC, Townsley CC (1986) The uptake of heavy metals by filamentous fungi. In: Eccles HH, Hunt S, Immobilization of lons by Biosorption Ellis Horwood, Chichester, West Sussex England.
75. Huang CP, Westman D, Quirk K, Huang JP (1988) The removal of cadmium (II) from dilute aqueous solutions by fungal adsorbent. Water Sci Technol 20 369-376.

76. Kiff RJ, Little DR (1986) Biosorption of heavy metals by immobilized fungal biomass. In: Eccles HH, Hunt S, Immobilization of Ions by Biosorption. Ellis Horwood, Chichcster, UK.

77. Kurek E, Czaban J, Bollag JM (1982) Sorption of cadmium by microorganisms in competition with other soil constituents. Appl Environ Microbiol 43: 1011 1015.

78. Pal A, Ghosh S, Paul AK (2006) Biosorption of cobalt by fungi from serpentine soil of Andaman. Bioresour Technol 97: 1253-1258.

79. Ashida J (1965) Adaptation of fungi to metal toxicants. Ann Rev Phytopathol 3: 153-174.

80. Babich H, Stotzky G (1983) Synergism between nickel and copper in their toxicity to microbes: mediation by pH. Ecotoxicol Environ Saf 7: 576-587.

81. Castro F, Viedma P, Cotorás D (1992) [Biomass of Rhizopus oligosporus as an adsorbent for metal ions]. Microbiologia 8: 94-105.

82. Chang JS, Huang JC (1998) Selective adsorption/recovery of $\mathrm{Pb}, \mathrm{Cu}$, and $\mathrm{Cd}$ with multiple fixed beds containing immobilized bacterial biomass. Biotechnol Prog 14: 735-741.

83. Srivastava PK, Vaish A, Dwivedi S, Chakrabarty D, Singh N, et al. (2011) Biological removal of arsenic pollution by soil fungi. Sci Total Environ 409: 2430-2442.

84. Cao L, Jiang M, Zeng Z, Du A, Tan H, et al. (2008) Trichoderma atroviride F6 improves phytoextraction efficiency of mustard (Brassica juncea (L.) Coss. var. foliosa Bailey) in Cd, Ni contaminated soils. Chemosphere 71: 1769-1773.

85. Raspanti E, Cacciola SO, Gotor C, Romero LC, García I (2009) Implications of cysteine metabolism in the heavy metal response in Trichoderma harzianum and in three Fusarium species. Chemosphere 76: 48-54.

86. Babu AG, Shim J, Bang KS, Shea PJ, Oh BT5 (2014) Trichoderma virens PDR28: a heavy metal-tolerant and plant growth-promoting fungus for remediation and bioenergy crop production on mine tailing soil. J Environ Manage 132 129-134.

87. Tsekova K, Todorova D (2002) Copper (II) accumulation and superoxide dismutase activity during growth of Aspergillus niger B-77. Z Naturforsch C 57: 319-322.

88. Subramanyam C, Gupta PD (1986) Glycogen deposition in Neurospora crassa under conditions of copper toxicity: a correlative ultra-structural and biochemical study. Microbiologica 45: 55-62.

89. Venkateswerlu G, Stotzky G (1986) Copper and cobalt alter the cell wal composition of Cunninghamella blakesleeana. Can J Microbiol 32: 654-662.

90. Gadd GM, Griffiths AJ (1977) Microorganisms and heavy metal toxicity. Microb Ecol 4: 303-317.

91. López Errasquín E, Vázquez C (2003) Tolerance and uptake of heavy metals by Trichoderma atroviride isolated from sludge. Chemosphere 50: 137-143. 